\title{
Effectiveness of groundwater governance structures and institutions in Tanzania
}

\author{
J. L. Gudaga' ${ }^{1}$ S. J. Kabote ${ }^{1}$ (1) A. K. P. R. Tarimo ${ }^{2}$ - D. B. Mosha ${ }^{3}$. J. J. Kashaigili ${ }^{4}$
}

Received: 22 November 2017 / Accepted: 30 April 2018 / Published online: 8 May 2018

(c) The Author(s) 2018

\begin{abstract}
This paper examines effectiveness of groundwater governance structures and institutions in Mbarali District, Mbeya Region. The paper adopts exploratory sequential research design to collect quantitative and qualitative data. A random sample of 90 groundwater users with 50\% women was involved in the survey. Descriptive statistics, Kruskal-Wallis H test and MannWhitney U test were used to compare the differences in responses between groups, while qualitative data were subjected to content analysis. The results show that the Village Councils and Community Water Supply Organizations (COWSOs) were effective in governing groundwater. The results also show statistical significant difference on the overall extent of effectiveness of the Village Councils in governing groundwater between villages $(P=0.0001)$, yet there was no significant difference $(P>0.05)$ between male and female responses on the effectiveness of Village Councils, village water committees and COWSOs. The Mann-Whitney U test showed statistical significant difference between male and female responses on effectiveness of formal and informal institutions $(P=0.0001)$, such that informal institutions were effective relative to formal institutions. The Kruskal-Wallis $\mathrm{H}$ test also showed statistical significant difference $(P \leq 0.05)$ on the extent of effectiveness of formal institutions, norms and values between low, medium and high categories. The paper concludes that COWSOs were more effective in governing groundwater than other groundwater governance structures. Similarly, norms and values were more effective than formal institutions. The paper recommends sensitization and awareness creation on formal institutions so that they can influence water users' behaviour to govern groundwater.
\end{abstract}

Keywords Groundwater · Governance $\cdot$ Structures $\cdot$ Formal institutions $\cdot$ Informal institutions $\cdot$ Mbarali district $\cdot$ Tanzania

\section{Introduction}

In Sub-Saharan African countries, the debate on water governance including groundwater has gained momentum in recent years. It is increasingly recognized that water governance is fundamental in enhancing effective water resource management. Thus, to achieve the intended objectives

\section{S. J. Kabote}

sjkabote@sua.ac.tz

1 Department of Development Studies, Sokoine University of Agriculture, Morogoro, Tanzania

2 Department of Engineering Sciences and Technology, Sokoine University of Agriculture, Morogoro, Tanzania

3 Institute of Continuing Education, Sokoine University of Agriculture, Morogoro, Tanzania

4 Department of Forest Resource Assessment and Management, Sokoine University of Agriculture, Morogoro, Tanzania related to water management in a respective country, there should be well-built water governance at regional, national and local levels. According to Stefano et al. (2014), water governance comprises structures and institutions. The role of the water governance structures is to implement decisions about policies, laws, regulations, incentives and capacity development on water resource management (Durant et al. 2004). Water institutions are underlying practices that purposefully shape and control human behaviour in using and managing water resource (Merrey and Cook 2012). These are shared social guidelines for governance structures and stakeholders on how, when, to whom, why and where the resource should be managed, accessed and utilized.

This paper is devoted to groundwater that has very little governance information in the literature in Tanzania. Principally, the occurrence of groundwater is largely influenced by geological conditions (Kashaigili 2013). About $75 \%$ of Tanzania (Kongola et al. 1999) is underlain by crystalline basement complex rocks which form the basement aquifers 
like the Pangani and Makutopora basins. Other aquifer types include the Karroo found in Tanga, coastal sedimentary formation of limestone and sandstone in Dar es Salaam, and the alluvial sedimentary sequence, which mostly include clay, silt, sand and gravel, and volcanic materials found in Kahe, Pangani basin. The groundwater potential of each main aquifer type differs much from place to place or basin-wise due to variability in aquifer formations and recharge mechanisms (Kashaigili 2013).

In Tanzania like other countries elsewhere, there are water governance structures that operate at various levels to govern surface water. At the national level, water resource is governed by the Ministry of Water and Irrigation through Water Basin Authorities (URT 2002). In line with the agreement from the International Conference on Water and Environment (ICWE) that was held in 1992 in Dublin, Ireland, and in Rio de Janeiro, Brazil (Calder 2005; Mosha et al. 2016), the country is promoting decentralization principles for water governance. The concept of decentralization refers to changing power relations whereby public functions authority and responsibility are transferred from the central government to local authorities or quasi-independent government organizations or to the private sector for effective water governance (Litvack and Seddon 1999; Mirumachi and Wyk 2010). Thus, the central government has transferred the power of water governance to the local government authorities at district and village levels. To that effect, governance structures including Village Councils, Community Water Supply Organisations (COWSOs), Water Supply and Sanitation Authorities and District authorities are captioned by the Water Resource Management Acts (WRMA) no 11 and 12 of 2009 being responsible for water management. In some villages, there are water committees and or Water Users Associations (WUAs) instead of COWSOs.

Another area of concern on surface and groundwater governance is about institutions. Tanzania has no specific institutions dedicated for groundwater governance apart from water institutions that are established to govern surface water (URT 2009). The formal water institutions include the National Water Policy (NAWAPO) of 2002 and Water Resource Management Acts (WRMA) no 11 and 12 of 2009. These guide water agencies to construct rules and regulations for water governance (Mosha et al. 2016) in controlling behaviour of the water users. In addition, formal institutions operate concomitantly with informal institutions in an overlapping fashion. Merrey and Cook (2012) differentiate formal and informal institutions as follows: formal institutions exist through constitutions, laws and defined property rights, while informal ones exist through customs, norms and codes of conduct, social taboos and practices related to resource use in a given locality.

Although governance structures and institutions look like different entities, it is undeniable that the two are dependent to each other in achieving intended objectives for water governance. The effectiveness of the decentralized water governance structures is explained by a number of issues including transparency, coordination, accountability and participation in the water governance (Hoekstra 2006; Garduño et al. 2011). Furthermore, fair water distribution, equal access to water, mutual respect among water users and water management priorities among others are necessary for water governance.

Previous studies including Kabote and John (2017) investigated performance of surface water governance structures and institutions in Tanzania. Their study indicates that some Village Water Committees and the Water Basin Board are weak with regard to influencing water users' behaviour to manage and govern water resource. However, there is dearth information regarding the extent of effectiveness of groundwater governance. This paper seeks answers to the following questions: (i) what are the existing groundwater governance structures in the study area? (ii) To what extent groundwater governance structures are effective in governing water resource? (iii) What are the existing groundwater institutions and to what extent are effective in governing groundwater? Knowing the effectiveness of groundwater governance helps to maintain, develop and/or improve the existing water governance system.

\section{Methodology}

The study was conducted in Mbarali District, Mbeya Region. Mbarali is one of the districts that are found in semi-arid environment in Tanzania. The reason for selecting the district for study is that it is essential for two things: first, it's a critical area for paddy production and a source of water for Great Ruaha River that serves water to Ruaha National Park ecology. The River is also a source of water for Mtera, Kidatu and Kihansi hydroelectric power plants in the country. All these activities depend on surface water that is dwindling because of many factors like drought and climate change. As such, the use of groundwater for socio-economic activities including domestic and irrigation is promoted to help sustain water in the Great Ruaha River. The district covers an area of 16, 632 square kilometres and has a population of 300,517 (URT 2014). It is located at latitude: $8^{\circ} 51^{\prime}$ $\left(8.85^{\circ}\right)$ south, longitude: $33^{\circ} 51^{\prime}\left(33.85^{\circ}\right)$ east. Altitude is almost low ranging from 1000 to 1800 metres above sea level (Kangalawe et al. 2012). The minimum temperature is $19{ }^{\circ} \mathrm{C}$ between June and July, while the maximum is $35^{\circ} \mathrm{C}$ that occurs between August and December (Kangalawe et al. 2012). Administratively, the district is divided into 20 wards with a total of 99 villages. The main soil characteristics in Mbarali District are dark grey and prismatic cracking clays. In Mbarali, water resources including groundwater laid in 
the Great Ruaha River Catchment, which is one of the four sub-basins of the Rufiji River Basin. The average rainfall is $600 \mathrm{~mm}$ per year, which falls between December and April, and hence, the district is vulnerable to water scarcity (Kayombo 2016; Sirima 2016). This explains the prevalence and high prominence of groundwater use, which is extracted from shallow wells and boreholes (Pavelic et al. 2012).

\section{Research design, sampling and data collection techniques}

The study employed an exploratory sequential cross-sectional research design that allows data collection at a single point in time, and it is most appropriate for descriptive and determination of relationships between variables (Babbie 2007). Time limit and resource available for data collection led to the adoption of cross-sectional research design in this study (Casley and Kumar 1988). The sampling procedures involved purposive selection of three out of 99 villages in the district. The villages were Nyeregete, Ubaruku and Mwaluma. These were selected based on the evidence that there were groundwater sources mainly for domestic uses. In each village, 30 groundwater users were randomly selected making a sample size of 90 respondents.

Data collection methods included groundwater users' survey, focus group discussions (FGDs) and key informant interviews. There were two rounds of data collection. The first round dealt with qualitative data collection and analysis and informed the second round in terms of refining questions to quantify variables. One FGD was conducted in each village making a total of three FGDs. We used sex and age as criteria for selecting FGDs participants in order to get different experiences and perceptions of groundwater governance issues from male and female water users, and also from different age groups. Each FGD comprised 8-12 participants. The proportion of female participants in each FGD ranged from 5 to 7. Females were involved in FGDs because they are responsible for fetching water for domestic uses at a household level. The FGDs and key informant interviews were used to explore the existence and responsibilities of local level water governance structures. The Village Executive Officers (VEOs) from each village and the chairperson of Ubaruku Mpakani (UBAMPA) were involved as the key informants. The UBAMPA is one of the Community Water Supply Organizations (COWSOs) that serves for Ubaruku and Mpakani villages. The key informants were selected based on the fact that they are responsible for groundwater governance at the village level. In addition, the survey guided by a questionnaire was used to collect quantitative data on demographic characteristics and respondents' responses on the extent to which water governance structures and institutions achieved the intended objectives with regard to groundwater governance.
It is important to mention that ethical issues were considered in the design of the study. The proposal for the study was evaluated and approved by the Senate Postgraduate Studies Committee of the Department of Development Studies at Sokoine University of Agriculture, chaired by Dr. Emmanuel T. Malisa. This was followed by issuing a research clearance letter by the Vice Chancellor, by then Prof. Gerald Monela, that was submitted to the local leaders in the study area after which an agreement was made to conduct the study. An oral informed consent from all the respondents was sought before the interviews. Participation in the study was voluntary, and therefore, respondents were free to participate or not.

\section{Data analysis}

Quantitative data were analysed by using Statistical Package for Social Sciences (SPSS). An index summated scale was used to measure the extent of effectiveness of groundwater governance structures and institutions. A total of 12 statements were used to measure groundwater institutions including formal institutions, norms and values, while a total of 21 statements were used to measure effectiveness of groundwater governance structures including Water Committees, Village Councils and COWSOs. Every respondent was asked to respond whether he/she strongly disagreed (1 score), disagreed ( 2 scores), neutral (3 scores), agreed (4 scores) or strongly agreed (5 scores) on each item of the scale. The median was used as a cut-off point between low, medium and high effectiveness. The score below median represented low effectiveness, the median represented medium effectiveness, and the score above the median represented high effectiveness of groundwater governance institutions and structures.

Reliability analysis was used to assess internal consistence of the scale. In this study, the scale showed acceptable internal consistency with a Cronbach's alpha value of 0.81 and 0.73 for institutions and structures, respectively. According to George and Mallery (2003), an alpha value of 0.7 and above is acceptable. Cross-tabulations were used to compare the extent of effectiveness between the villages. The Kruskal-Wallis H test was used to determine whether there was statistical significant difference between the villages on effectiveness of the structures. This is a nonparametric test useful in determining significant differences for more than two independent groups for ordinal dependent variable (Pallant 2007). The Mann-Whitney $U$ test was used to compare the median difference between the overall effectiveness of water governance institutions and structures between male and female responses. The test is useful to assess statistical significant differences in ordinal data when two independent groups are compared, in this, case male and female responses (Pallant 2007). 


\section{Results and discussion}

\section{Respondents' characteristics}

Table 1 presents respondents' characteristics. The results show that half $(50 \%)$ of the respondents were males. This was intended to avoid bias between male and female groundwater users' responses on effectiveness of water institutions and structures. The results also show that 58.9 and $33.3 \%$ of the respondents were household heads and spouses, respectively. In addition, livelihoods of $62.2 \%$ of the respondents depended on farming. This implies that majority of the respondents were smallholder farmers. The literature shows that about $70 \%$ of the Tanzania work force depends on the agricultural sector for the livelihoods (Lwoga et al. 2011).
The results also show that $72.2 \%$ of the respondents were married. In addition, 80 and $64.4 \%$ were married male and female, respectively. The analysis also shows that $53.3 \%$ of the respondents held primary education (Table 1). This indicates that the majority had acquired basic education. Education is a major means of providing individuals with ability to manipulate groundwater structures and institutions to improve groundwater governance. This includes the ability of acquiring knowledge, skills, values and attitudes needed for various social and economic development (URT 2000). In relation to water governance, low education can hinder the effectiveness of groundwater governance structures for governing groundwater resource. For instance, governance structures' members have to be aware about formal and informal rules of the game. Since formal rules of the game

Table 1 Respondents' characteristics $(n=90)$

\begin{tabular}{|c|c|c|c|c|}
\hline Sex & Nyeregete & Ubaruku & Mwaluma & Total \\
\hline Male & $15(50)$ & $15(50)$ & $15(50)$ & $45(50)$ \\
\hline Female & $15(50)$ & $15(50)$ & $15(50)$ & $45(50)$ \\
\hline Total & $30(100)$ & $30(100)$ & $30(100)$ & $90(100)$ \\
\hline \multicolumn{5}{|c|}{ Relationship to the household head } \\
\hline Head of household & $22(73.3)$ & $16(53.3)$ & $15(50)$ & $53(58.9)$ \\
\hline Spouse & $7(23.3)$ & $8(26.7)$ & $15(50)$ & $30(33.3)$ \\
\hline Son & $0(0.0)$ & $3(10)$ & $0(0.0)$ & $3(3.3)$ \\
\hline Daughter & $1(3.3)$ & $3(10.0)$ & $0(0.0)$ & $4(4.4)$ \\
\hline Total & $30(100)$ & $30(100)$ & $30(100)$ & $90(100)$ \\
\hline \multicolumn{5}{|l|}{ Main source of income } \\
\hline Farming & $20(66.7)$ & $20(66.7)$ & $16(53.3)$ & $56(62.2)$ \\
\hline Livestock keeping & $1(3.3)$ & $2(6.7)$ & $1(3.3)$ & $4(4.4)$ \\
\hline Small-scale business & $6(20.0)$ & $7(23.3)$ & $4(13.3)$ & $17(18.9)$ \\
\hline Casual labour & $0(0.0)$ & $0(0.0)$ & $2(6.7)$ & $2(2.2)$ \\
\hline Salary & $3(10.0)$ & $1(3.3)$ & $7(23.3)$ & $11(12.2)$ \\
\hline \multirow[t]{2}{*}{ Total } & $30(100.0)$ & $30(100.0)$ & $30(100.0)$ & $90(100.0)$ \\
\hline & \multicolumn{2}{|c|}{ Male } & Female & Total \\
\hline \multicolumn{5}{|l|}{ Marital status } \\
\hline Married & \multicolumn{2}{|c|}{$36(80.0)$} & $29(64.4)$ & $65(72.2)$ \\
\hline Single & \multicolumn{2}{|c|}{$4(8.9)$} & $2(4.4)$ & $6(6.7)$ \\
\hline Divorced & \multicolumn{2}{|c|}{$1(2.2)$} & $5(11.1)$ & $6(6.7)$ \\
\hline Widowed/widower & \multicolumn{2}{|c|}{$4(8.9)$} & $9(20.0)$ & $13(14.4)$ \\
\hline Total & \multicolumn{2}{|c|}{$45(100)$} & $45(100)$ & $90(100)$ \\
\hline \multicolumn{5}{|l|}{ Education level } \\
\hline Non-formal education & \multicolumn{2}{|c|}{$10(22.2)$} & $8(17.8)$ & $18(20.0)$ \\
\hline Primary education & \multicolumn{2}{|c|}{$26(57.8)$} & $22(48.9)$ & $48(53.3)$ \\
\hline Secondary & \multicolumn{2}{|c|}{$3(6.7)$} & $12(26.7)$ & $15(16.7)$ \\
\hline Tertiary education & \multicolumn{2}{|c|}{$3(6.7)$} & $2(4.4)$ & $5(5.6)$ \\
\hline Higher learning education & \multicolumn{2}{|c|}{$3(6.7)$} & $1(2.2)$ & $4(4.4)$ \\
\hline Total & \multicolumn{2}{|c|}{$45(100)$} & $45(100)$ & $90(100)$ \\
\hline
\end{tabular}

Numbers in brackets are percentages 
are documented, it requires formal education to enable the players, who are the water users to practice the rules.

Table 2 shows respondents' age, household size, total number of years a household resided in the village and household annual income. The mean age of the respondents was 43 years, with a standard deviation of 12.1 years. This implies that majority of the respondents were young adults who are critical for water resource governance. The results also show that the mean number of persons per household was 5.9. This number is above 4.9 persons reported at the national level in Tanzania (URT 2012). Larger households generally require larger amount of water for domestic use. Thus, abiding and practising water institutions are imperative for sustainable water governance.

Furthermore, Table 2 shows that the total mean number of years in which respondents lived in the village was 18.4 years with a standard deviation of 10.9. This shows that the respondents had lived enough period of time for them to have experience regarding groundwater structures and institutions in the study area. The results in Table 2 also show that the mean households' annual income was Tanzania Shillings (TZS) 3, 074, 500, equivalent to TZS 256, 208 per month per household. This amount is higher than the mean annual income reported at a national level, which is TZS 146,000 per month per household in Tanzania (URT 2012). The higher mean annual income in the study area is possibly associated with the potential socio-economic activities including paddy production that are undertaken in the Usangu plain including Mbarali District (Ngailo et al. 2016).

\section{Governance structures}

Through focus group discussions (FGDs) and key informant interviews, the results show that there were two governance structural set-ups in the study area. Figure 1 presents governance structural set-up at Nyeregete and Mwaluma villages, while Fig. 2 presents governance structural arrangement in Ubaruku village. The figures indicate
Table 2 Descriptive statistics on respondents' characteristics $(n=90)$

Fig. 1 Groundwater governance structural set-up in Mwaluma and Nyeregete villages. NB: Straight line means two-way strong exchange of information between the water governance structures. Dotted line means two-way weak exchange of information between the water governance structures

\begin{tabular}{lllll}
\hline Variable & Minimum & Maximum & Mean & SD \\
\hline Age of the respondent & 22 & 72 & 43.2 & 12.1 \\
Total number of people in the household & 2 & 11 & 5.9 & 1.8 \\
Total number of years the HH resided in a village & 3 & 50 & 18.4 & 10.9 \\
Annual household income & 350,000 & $15,000,000$ & 3074500 & $3,177,319$ \\
\hline
\end{tabular}

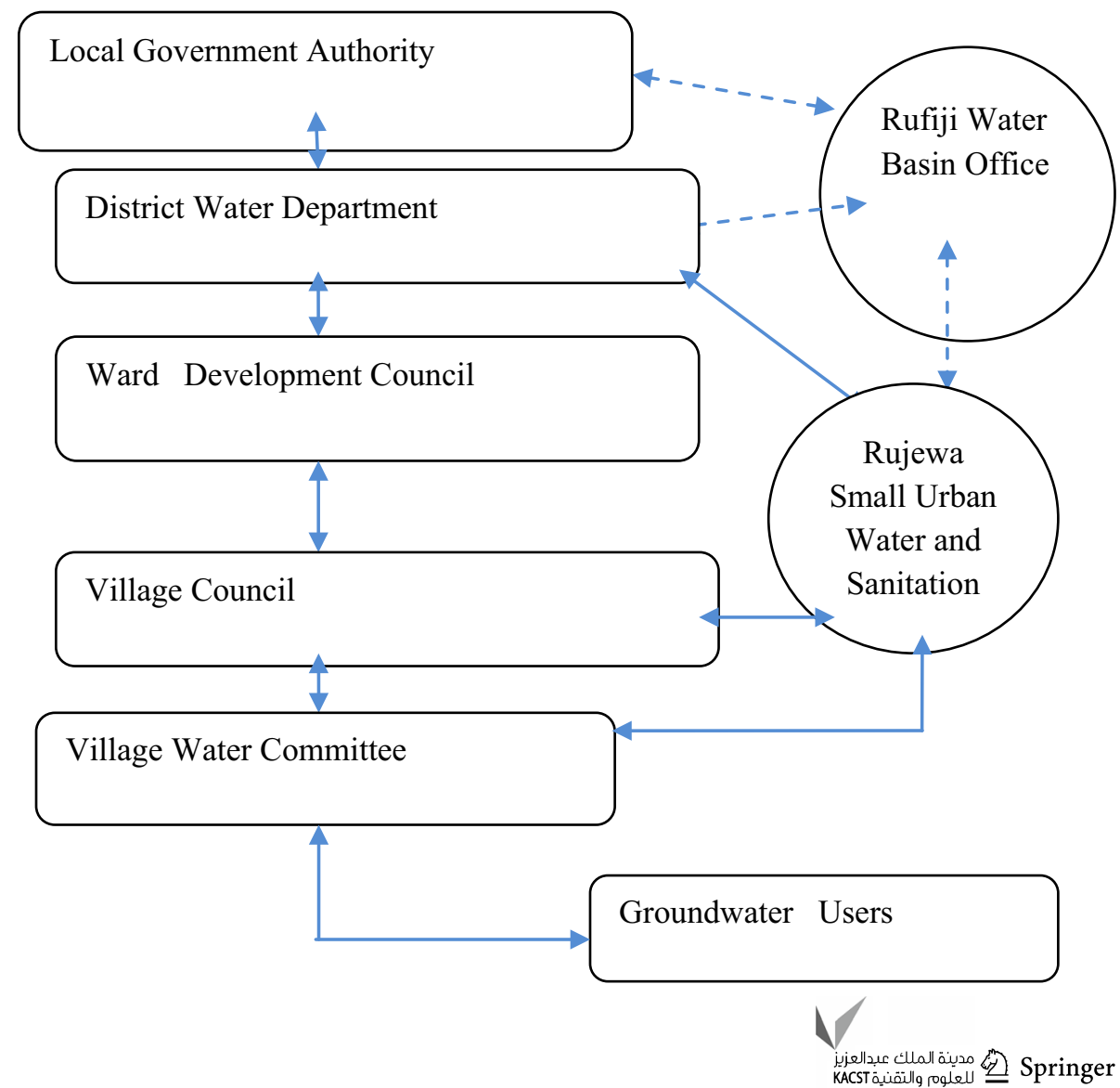


Fig. 2 Groundwater governance structure in Ubaruku village. NB: Straight line means two-way strong exchange of information between the Dotted line means two-way weak exchange of information between the water governance structures water governance structures.

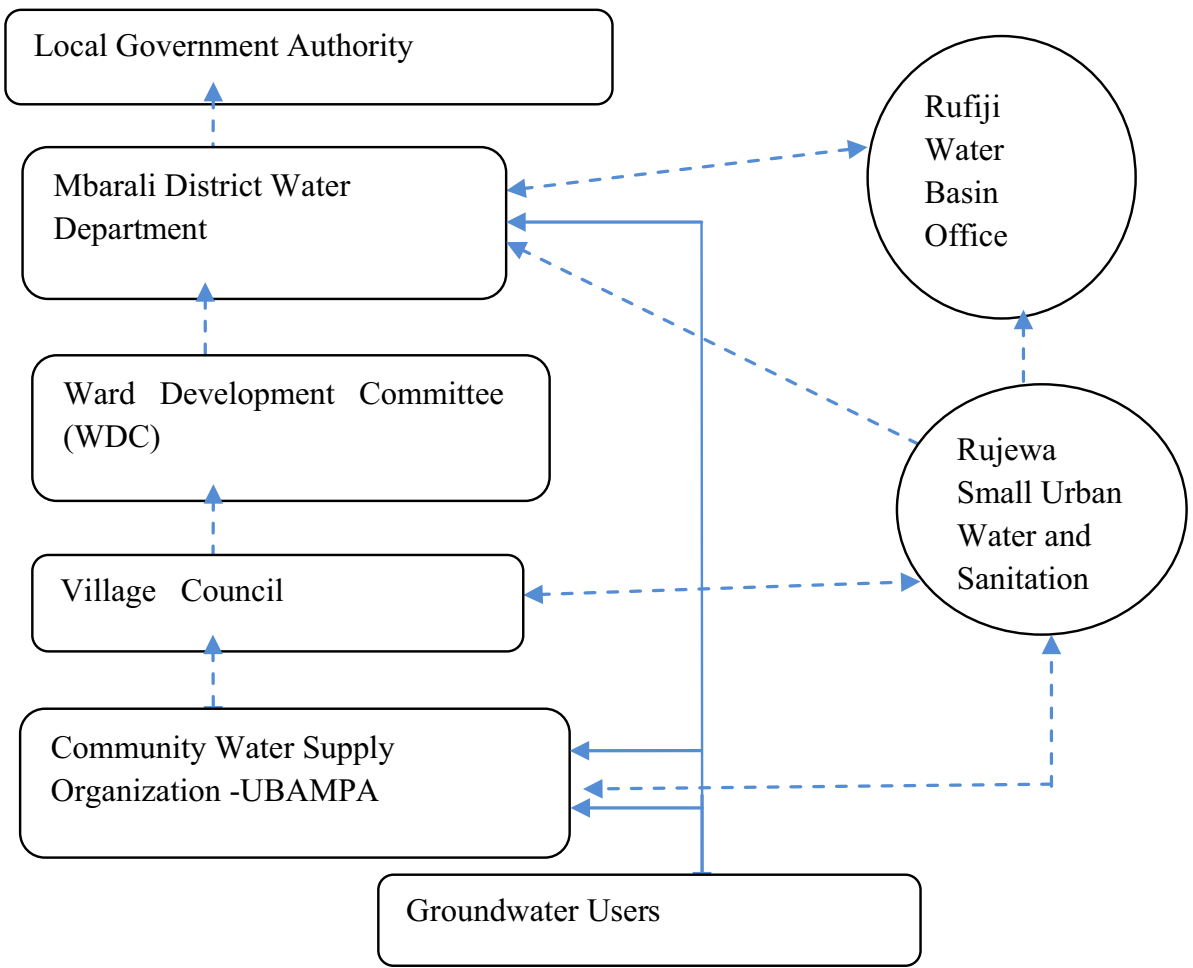

an existing relationship among the structures in governing groundwater. The Water Committees and Village Councils were responsible groundwater structures in the villages. In addition, water governance involved external structures within the District such as Ward Development Council (WDC), Rujewa Small Urban Water Sanitation Authority, Mbarali Water Department and Mbarali Local Government Authority. Water governance structures within the District had to fulfil their responsibilities in accordance to the Rufiji Water Basin Authorities, responsible for water governance at a national level.

During key informant interviews, participants reported that there was two-way exchange of information from the Local Government Authorities, at a district and village level, to groundwater users through groundwater governance structures. They also reported weak relationship between the Rufiji Water Basin Office and the Local Government Authority through District Water Department and Rujewa Small Urban Water and Sanitation Authorities as presented in the following quotation:

We as a District Water Department officials work closely with all water structures at the local level. For instance, we receive water development plans from villages via Ward Development Committees to the Mbarali District Council; we provide technical support of groundwater related issues such as maintenance of water pumps. But the Rufiji Water Basin is not close to the local government water related offices to make follow-up on groundwater governance issues.

In Ubaruku village, the governance structural set-up was a bit different compared to Nyeregete and Mwaluma villages (Fig. 2). The village had COWSO instead of water committees. The COWSO was registered since 2015 at the district council. The objective of COWSO is to ensure that water service is accessible to the local people. Since Council, the results show that there was direct relationship between the COWSO and the District Council as well as groundwater users. However, the relationships between the COWSO and other structures such as Village Council, WDC, Rujewa Small Urban Water and Sanitation Authorities were weak. Such situation led to misunderstanding between the COWSO, the Village Council and the groundwater users. For example, the COWSO leaders failed to provide financial report to the groundwater users because they did not have mandate to call for public meetings to provide the report as shown in the following quotation from one of the key informants:

We have a report but the village leaders are not willing to call village meetings until we agree that the COWSO will be operating under the Village Council. The COWSO is not willing to become responsible to the Village Council because it is registered and responsible to the district level. COWSO is registered and responsible to the District 
Another quotation from one of the Village Councils is as follows:

In this village we don't have Water Committee but we have COWSO known as Ubaruku Mpakani (UBAMPA). The COWSO is composed of 5 members from each hamlet and two members of the Village Council. Although it is registered, it is a structure that should operate under the Village Council and should submit a report to the Village Council meetings; then we, as a Village Council, should call for public meetings so as to present groundwater financial reports.

Based on that quotation, the Village Council is a fundamental structure that oversees all village development activities including groundwater governance. The structure via the Village Executive Officer had to channel water development plans to the Ward Development Committee (WDC) then to the district council via Rujewa Small Urban Water and Sanitation Authority or District Water Department.

The contradictions that existed in Ubaruku between the COWSO and Village Council raises some questions. For example, to which structure the COWSO should be responsible? Does the registration at the District Council shift the power of the Village Council to oversee groundwater governance? Are there clear directives that guide how the COWSO and the Village Council should operate interdependently? A good thing is that the WRMA no 12 of 2009 states clearly the functions of the district authorities, COWSOs and Village Councils on water governance. One of the district authorities' functions is to facilitate registration of community organisations, while the Village Council is responsible for promoting establishment of COWSOs, coordinating COWSOs' budgets with Village Council budgets and resolving conflicts arising within the community organisations (URT 2009). The contradiction on groundwater governance between the Village Council and COWSO leadership in Ubaruku village highlights that there was a limited directives on how the COWSO should operate parallel with other water governance structures at a village level.

Based on the presented governance structural arrangements, the study proposes that the groundwater governance structural set-up (Fig. 2) is more effective because all responsibilities of the structures including Village Council and COWSO are clearly stipulated in WRMA. This gives power to the water governance structures to fulfil their responsibilities cordially to the water management decentralization objectives. However, a clear line with regard to information flow between the structures, responsibilities and accountability remains essential to avoid and/or minimize conflicts among the actors.

\section{Responses on the effectiveness of groundwater governance structures}

Table 3 presents degree of success of Water Committees in governing groundwater resource. Overall, the columns for disagree and strongly disagree suggest that the Village Water Committees were not effective in terms of contributing money for pump maintenance, allocating fair distribution of water points, resolving groundwater-related conflicts, providing financial report to the groundwater users and enhancing accountability to all groundwater users for groundwater governance. However, the results indicate that the committees were effective in terms of sensitizing groundwater protection against pollution and overseeing the implementation of groundwater norms and values in the study area.

Looking at the columns for agree and strongly agree, the results show that the Village Councils were effective in addressing groundwater issues in public meetings, enhancing community active participation, providing groundwater-related financial reports, setting priorities, plans and activities related to groundwater governance, promoting accountability of groundwater users on water management and overseeing the implementation of the groundwater bylaws, norms and values (Table 4).

Table 3 Respondents' responses on the effectiveness of water committee $(n=60)$

\begin{tabular}{|c|c|c|c|c|c|}
\hline Statements & Strongly disagree & Disagree & Neutral & Agree & Strongly agree \\
\hline $\begin{array}{l}\text { Water committee facilitates groundwater users to contribute money for } \\
\text { pump maintenance }\end{array}$ & 11(18.3) & $18(30.0)$ & $9(15.0)$ & $21(35.0)$ & $1(1.6)$ \\
\hline Water committee has led to fair distribution of groundwater points & $12(20.0)$ & $17(28.3)$ & $9(15.0)$ & $22(36.6)$ & $0(0.0)$ \\
\hline Water committee resolves groundwater-related conflicts effectively & $3(5.0)$ & $35(58.3)$ & $16(26.6)$ & $4(4.4)$ & $2(3.3)$ \\
\hline Water committee provides financial report to groundwater users timely & $2(3.3)$ & $38(42.2)$ & $3(5.0)$ & $15(25.0)$ & $2(3.3)$ \\
\hline $\begin{array}{l}\text { Water committee has led accountability to all groundwater users on ground- } \\
\text { water management }\end{array}$ & $3(5.0)$ & $28(46.6)$ & $9(15.0)$ & $17(28.3)$ & $3(5.0)$ \\
\hline Water committee sensitizes strongly on groundwater source conservation & $5(8.3)$ & $7(11.6)$ & $4(6.6)$ & $26(43.3)$ & $18(30.0)$ \\
\hline $\begin{array}{l}\text { Water committee oversees the implementation of groundwater-related norms } \\
\text { and values in the village }\end{array}$ & $5(8.3)$ & $6(10.0)$ & $5(8.3)$ & $42(70.0)$ & $2(3.3)$ \\
\hline
\end{tabular}

Numbers in brackets are percentages 
Table 4 Respondents' responses on the effectiveness of Village Councils $(n=90)$

\begin{tabular}{|c|c|c|c|c|c|}
\hline Statement & Strongly disagree & Disagree & Neutral & Agree & Strongly agree \\
\hline $\begin{array}{l}\text { Village Council addresses groundwater management issues at the public } \\
\text { meetings }\end{array}$ & $1(1.1)$ & 12(13.3) & $1(1.1)$ & $(60.0)$ & $22(24.4)$ \\
\hline $\begin{array}{l}\text { Village Council enhances active participation of the community on ground- } \\
\text { water management }\end{array}$ & $5(5.5)$ & $27(30.0)$ & $12(13.3)$ & $39(43.3)$ & $7(7.7)$ \\
\hline Village Council provides groundwater-related financial reports & $5(5.5)$ & $16(17.7)$ & $12(13.3)$ & $0(44.4)$ & $17(18.8)$ \\
\hline $\begin{array}{l}\text { Village Council sets priorities, plans and activities related on groundwater } \\
\text { management }\end{array}$ & $5(5.5)$ & $21(23.3)$ & $19(21.1)$ & $(43.3)$ & $6(6.6)$ \\
\hline $\begin{array}{l}\text { Village Council promotes accountability of groundwater users on water } \\
\text { management }\end{array}$ & $5(5.5)$ & $15(16.6)$ & $10(11.1)$ & $(62.2)$ & $4(4.4)$ \\
\hline $\begin{array}{l}\text { Village Council oversees the implementation of the related groundwater by- } \\
\text { laws, norms and values }\end{array}$ & $15(16.6)$ & $15(16.6)$ & $10(11.1)$ & (51.1) & $4(4.4)$ \\
\hline
\end{tabular}

Numbers in brackets are percentage

Based on the columns for agree and strongly agree, the results show that COWSO was effective on locating groundwater points fairly, resolving groundwater-related conflicts, establishing relationship with other water governance structures, enhancing accountability to all groundwater users on groundwater governance and overseeing the implementation of the related groundwater by-laws, norms and values. Nevertheless, the results show that COWSO was not effective in providing groundwater financial reports and enhancing fair say to all groundwater users on groundwater issues (Table 5).

\section{Extent of effectiveness of groundwater governance structures}

The results in Table 5 show that $60 \%$ of the respondents' responses show high effectiveness of groundwater governance structures. This is in line with the following quotation reported during one of the FGDs, indicating that the COWSO was effective in fulfilling its roles on groundwater governance.

The COWSO is very active and close to the groundwater users. It has established a system of paying water charges per bucket, fetching water in the presence of the water agent at every water point who collects water charges. Generally, the COWSO oversees all groundwater governance activities properly.

Table 5 Respondents' responses on the effectiveness of COWSO $(n=30)$

\begin{tabular}{|c|c|c|c|c|c|}
\hline Statement & Strongly disagree & Disagree & Neutral & Agree & Strongly Agree \\
\hline COWSO has led to fair distribution of groundwater points & $1(3.3)$ & $5(16.6)$ & $2(6.6)$ & 17(56.6) & $5(16.6)$ \\
\hline COWSO resolves groundwater-related conflicts efficiently & $2(6.6)$ & $5(16.6)$ & $2(6.6)$ & $15(50.0)$ & $6(20.0)$ \\
\hline COWSO provides financial report to groundwater users timely & $11(36.6)$ & $12(40.0)$ & $4(13.3)$ & $3(10.0)$ & $0(0.0)$ \\
\hline $\begin{array}{l}\text { COWSO has led fair saying to all groundwater users on resource manage- } \\
\text { ment }\end{array}$ & $6(20.0)$ & $10(33.3)$ & $8(26.6)$ & $5(16.6)$ & $1(3.3)$ \\
\hline COWSO has a proper relationship with other water governance structures & $8(26.6)$ & $2(6.6)$ & $5(16.6)$ & $13(43.3)$ & $2(6.6)$ \\
\hline $\begin{array}{l}\text { COWSO promotes accountability of all groundwater users on water resource } \\
\text { management }\end{array}$ & $3(10.0)$ & $3(10.0)$ & $3(10.0)$ & $14(46.6)$ & $7(23.3)$ \\
\hline $\begin{array}{l}\text { COWSO oversees the implementation of the related groundwater by-laws, } \\
\text { norms and values }\end{array}$ & $3(10.0)$ & $3(10.0)$ & $3(10.0)$ & $16(53.3)$ & $5(16.6)$ \\
\hline Extent of effectiveness & $n$ & & & & Per cent \\
\hline \multicolumn{6}{|l|}{ Effectiveness of COWSO in governing groundwater in Ubaruku village $(n=30)$} \\
\hline Low & 3 & & & & 10.0 \\
\hline Medium & 9 & & & & 30.0 \\
\hline High & 18 & & & & 60.0 \\
\hline
\end{tabular}

Numbers in brackets are percentage 
Figure 3 presents an overall effectiveness of Village Councils on water governance. The results show that $52.2 \%$ of the respondents reported high effectiveness of the Village Councils. About 53\% of the respondents in Ubaruku showed low effectiveness, while 73.3 and $63.3 \%$ in Nyeregete and Mwaluma villages, respectively, showed high effectiveness. There was poor relationship between the COWSO and the Village Council in Ubaruku village, which was associated with the factors that led to low effectiveness of the Village Council in the village. The governance structural set-up in Ubaruku village indicates that there was a strong relationship between the COWSO and groundwater users, but the relationship between the Village Council and groundwater users was weak. During FGDs, participants in Ubaruku reported that:

We appreciate the COWSO's commitment in providing water services in our village. Recently, the COWSO has planned to distribute water service in households. But, the Village Council is not cooperative to the COWSO initiatives about groundwater development.
That quotation justifies both positive and negative perceptions of groundwater users to the COWSO and Village Council, respectively, about groundwater governance. The results also show that $71.7 \%$ of the respondents reported medium effectiveness of the Village Water Committees (Fig. 4). This is in line with one of the key informants in Mwaluma village who reported that:

We have a water committee working under the Village Social Services standing committee. The committee is responsible for coordinating all water management activities in the village. However, the committee is not directly accountable to the Village Council but to the Village Social Services Committee (VSSC).

The VSSC is one of the village standing committees in Tanzania responsible for health, education and water management issues at a village level. Thus, the extent of effectiveness of the VSSC can also affect effectiveness of the water committee. The WRMA no 11 and 12 of 2009 do not recognize the presence of water committees unlike COWSOs at a village level (URT 2009). This largely explains the
Fig. 3 Effectiveness of Village Councils on groundwater governance
Fig. 4 Effectiveness of village water committees in governing groundwater
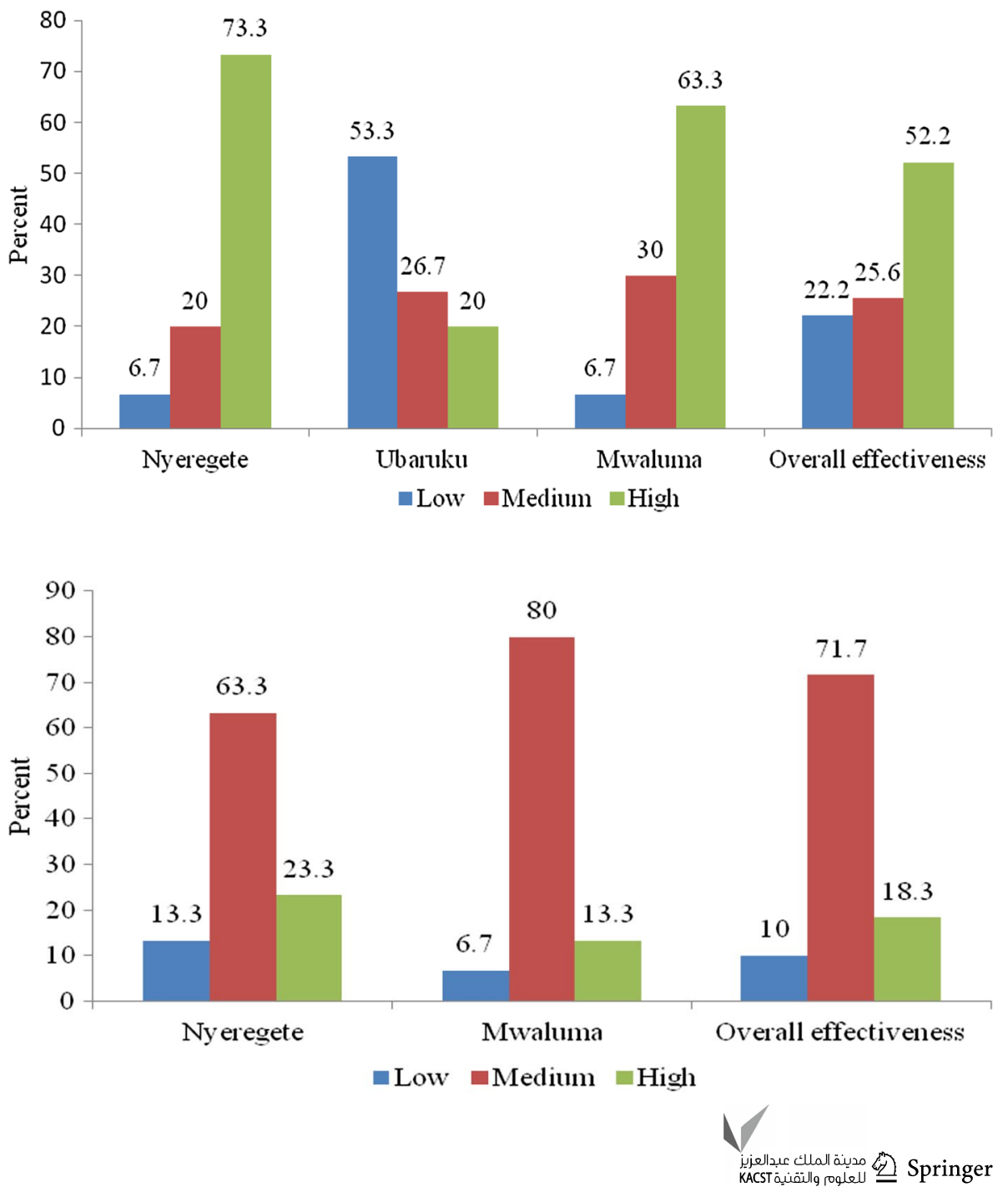
reasons for the Village Water Committees being reported medium effective.

Table 6 presents differences of the respondents' responses on the effectiveness of water committee, Village Council and the COWSO regarding groundwater governance. Based on the medians, the results show that the water committees, Village Councils and the COWSO were highly effective. Using Kruskals Walls H test, the results were statistically significant different among the respondents' responses on the effectiveness of Village Committees, Village Councils and the COWSO $(P=0.0001)$. The difference is attributed to various factors. For instance, the misunderstanding that existed between the Village Councils and the COWSO can lead into different perceptions on the effectiveness of the governance structures.

Using Mann-Whitney $U$ test, the results show that there was no statistically significant difference on the responses between male and female respondents on effectiveness of water committees, Village Councils and the COWSO on groundwater governance (Table 7). This implies that males

Table 6 Difference effectiveness extent of water governance structures

\begin{tabular}{|c|c|c|c|c|c|}
\hline & $n$ & Median & Chi-square & $d f$ & $P$ value \\
\hline \multicolumn{6}{|c|}{ Water committee } \\
\hline Low & 6 & 15.0 & & & \\
\hline Medium & 43 & 24.0 & 37.370 & 2 & 0.000 \\
\hline High & 11 & 28.0 & & & \\
\hline \multicolumn{6}{|c|}{ Village Council } \\
\hline Low & 20 & 15.0 & & & \\
\hline Medium & 23 & 27.0 & 51.259 & 2 & 0.000 \\
\hline High & 47 & 28.0 & & & \\
\hline \multicolumn{6}{|l|}{ cOWSO } \\
\hline Low & 3 & 13.0 & & & \\
\hline Medium & 9 & 21.0 & 15.856 & 2 & 0.000 \\
\hline High & 18 & 29.0 & & & \\
\hline
\end{tabular}

and females had similar views about the effectiveness of water governance structures.

During key informant interviews in Ubaruku village, it was reported that groundwater users, through their COWSO, had established water charges formal regulation. The regulation requires water users to pay TSZ 25 per bucket at the water point. There is a water agent at each water point who collects charges on behalf of the COWSO leadership. The COWSO's treasurer receives the collected water charges from the agents and deposits the money into a bank account for future use.

\section{Extent of effectiveness of groundwater governance institutions}

Table 8 presents respondents' responses on the effectiveness of formal institution. The results show that water charges regulation had led into improvement of groundwater provision services, sense of ownership among groundwater users, facilitating water governance structures to fulfil their responsibilities and proper use of groundwater at a household level. During key informant interviews, participants reported that, among other expenditures, water charges were used to improve water services. The COWSO established 23 water points within a village. The effectiveness of the COWSO was in line with the objectives of the WRMA no 11 and 12 of 2009. The objective of WRMA is to promote and ensure that every person in Tanzania access sustainable water supply and sanitation services (URT 2009). Nevertheless, the results revealed that there was lack of formal institutions which are responsible for groundwater governance. For instance, in Nyeregete and Mwaluma villages, formal institutions did not exist at all. This is supported by the existing literature, which shows that, in Tanzania, there are inadequate regulations set-ups for management of groundwater (Kabote and John 2017). Consistent to nonexistent of formal institutions in some villages, Gudaga et al. (2018) reported poor awareness of formal relative to informal institutions in the study area.
Table 7 Male and female responses on the effectiveness of water structures

\begin{tabular}{lllllll}
\hline $\begin{array}{l}\text { Sex of the } \\
\text { respondent }\end{array}$ & $n$ & Median & $U$ & Wilcoxon $\mathrm{W}$ & $\mathrm{Z}$ & $P$ value \\
\hline $\begin{array}{l}\text { Water committee } \\
\text { Male }\end{array}$ & 31 & 24 & & & \\
$\begin{array}{l}\text { Female } \\
\text { Village Council }\end{array}$ & 29 & 24 & 355.500 & 851.500 & -1.400 & 0.162 \\
Male & 45 & 22 & & & & \\
Female & 45 & 22 & 864.500 & 1899.500 & -1.200 & 0.230 \\
COWSO & & & & & \\
Male & 14 & 26 & & & & \\
Female & 16 & 26 & 105.000 & 210.000 & 0.770 & 0.790 \\
\hline
\end{tabular}


Table 8 Responses on the effectiveness of formal institutions in Ubaruku village $(n=30)$

\begin{tabular}{|c|c|c|c|c|c|}
\hline Statement & Strongly disagree & Disagree & Neutral & Agree & Strongly agree \\
\hline $\begin{array}{l}\text { Presence of water fee has led to improvement of groundwater provision } \\
\text { services }\end{array}$ & $0(0.0)$ & $0(0.0)$ & $2(6.6)$ & $25(83.3)$ & $3(10.0)$ \\
\hline Presence of water fee has led to groundwater users sense of ownership & $0(0.0)$ & $2(6.6)$ & $2(6.6)$ & $16(53.3)$ & $10(33.3)$ \\
\hline Water fee facilitates water governance structures to fulfil their roles & $2(6.6)$ & $2(6.6)$ & $1(3.3)$ & $17(56.6)$ & $8(26.6)$ \\
\hline $\begin{array}{l}\text { Presence of water fee has led to proper use of groundwater resource at the } \\
\text { household }\end{array}$ & $3(10.0)$ & $1(3.3)$ & $1(3.3)$ & $19(63.3)$ & $6(20.0)$ \\
\hline Category & $n$ & & & & Per cent \\
\hline \multicolumn{6}{|l|}{ Overall effectiveness of formal institutions in Ubaruku village $(n=30)$} \\
\hline Low & 3 & & & & 10.0 \\
\hline Medium & 17 & & & & 56.6 \\
\hline High & 10 & & & & 33.3 \\
\hline
\end{tabular}

Numbers in brackets are percentages

The results in Table 8 also show that $56.6 \%$ of the respondents reported formal institutions as medium effective in governing groundwater. During FGDs in Ubaruku village, it was reported that there was a by-law of paying water charges at the water point per bucket. This is supported by the following quotation:

Each water point has a responsible water agent who collects water charges of TZS 25 per bucket from groundwater users. The agent is accountable to the COWSO leadership.
Also, the COWSO chairperson reported that the by-law of water charges aims at generating funds for sustainable groundwater governance in the village.

Based on the results that are shown on the columns of agree and strongly agree in Table 9, the results show that 92.1, 94.3, 94.4 and $95.4 \%$ of the respondents reported that groundwater-related norms improved sanitation into water points, free of groundwater pollution at the water sources, mutual respect among groundwater users and pump safety, respectively. The literature reports that water governance including groundwater is largely dominated by informal institutions including norms at a local level (Kabote and

Table 9 Respondents' responses on the effectiveness of water (a) norms $(n=90)$ (b) values $(n=90)$

\begin{tabular}{|c|c|c|c|c|c|}
\hline Statement & Strongly disagree & Disagree & Neutral & Agree & Strongly agree \\
\hline \multicolumn{6}{|l|}{ (a) } \\
\hline $\begin{array}{l}\text { Restriction of washing buckets/objects at water point led to water point } \\
\text { sanitation }\end{array}$ & $0(0.0)$ & $1(1.1)$ & $6(6.6)$ & $50(55.5)$ & $33(36.6)$ \\
\hline $\begin{array}{l}\text { Restriction of carrying human activities nearly water point leads to free of } \\
\text { groundwater pollution at the water source }\end{array}$ & $0(0.0)$ & $3(3.3)$ & $2(2.2)$ & $53(58.8)$ & $32(35.5)$ \\
\hline $\begin{array}{l}\text { Restriction of using an offensive language leads to mutual respect among } \\
\text { groundwater users }\end{array}$ & $0(0.0)$ & $5(5.5)$ & $0(0.0)$ & $75(83.3)$ & $10(11.1)$ \\
\hline $\begin{array}{l}\text { Restriction of using extra force during to pump out groundwater leads to } \\
\text { pump safety }\end{array}$ & $0(0.0)$ & $2(2.2)$ & $2(2.2)$ & $62(68.8)$ & $24(26.6)$ \\
\hline \multicolumn{6}{|l|}{ (b) } \\
\hline $\begin{array}{l}\text { Groundwater community based management has led to participation on } \\
\text { groundwater resource management }\end{array}$ & $1(1.1)$ & $3(3.3)$ & $1(1.1)$ & $64(71.1)$ & $21(23.3)$ \\
\hline $\begin{array}{l}\text { Groundwater community based management led to accountability of all } \\
\text { groundwater users on resource management }\end{array}$ & $2(2.2)$ & $4(4.4)$ & $1(1.1)$ & $65(72.2)$ & $18(20.0)$ \\
\hline $\begin{array}{l}\text { Groundwater community based management led to integrity in protecting } \\
\text { groundwater infrastructures }\end{array}$ & $2(2.2)$ & $7(7.7)$ & $2(2.2)$ & $57(63.3)$ & $22(24.4)$ \\
\hline $\begin{array}{l}\text { Groundwater community based management led to transparency on the } \\
\text { related groundwater matters }\end{array}$ & $4(4.4)$ & $6(6.6)$ & $1(1.1)$ & $56(62.2)$ & $23(25.5)$ \\
\hline $\begin{array}{l}\text { Groundwater community based management led to equality on the access of } \\
\text { groundwater resource management }\end{array}$ & $4(4.4)$ & $2(2.2)$ & $1(1.1)$ & $65(72.2)$ & $18(20.0)$ \\
\hline
\end{tabular}

Numbers in brackets are percentages 
John 2017). This implies that norms were effective regarding groundwater governance. Informal institutions are a result of continuous interactions and practices of the water resource users in responding to the existing resource situation in a particular community.

Looking at the columns for agree and strongly agree in Table 9, the results show that groundwater values had led to improving participation, accountability, integrity, transparency and equality on groundwater governance issues by $94.4,92.2,87.7,87.7$ and $92.2 \%$, respectively. This implies that values were highly effective regarding groundwater governance.

Overall, the results in Fig. 5 show that $55.5 \%$ of the respondents agreed that norms showed high effectiveness in influencing groundwater governance. This implies that groundwater norms were powerful in manipulating people's behaviour, attitudes and perceptions regarding groundwater governance. On the effectiveness of groundwater values, overall, the results show that $54.4 \%$ of the respondents' responses showed high effectiveness (Fig. 6). This implies that, like the norms, groundwater values are critical in manipulating groundwater users' behaviour regarding groundwater governance. Thus, water governance structures should acknowledge and promote the groundwater values presented in Table 9 in mediating local communities for groundwater governance.

Fig. 5 Effectiveness of norms in governing groundwater

Fig. 6 Effectiveness of values in governing groundwater
Table 10 presents the differences in responses between male and female on the extent of formal institutions, norms and values effectiveness on groundwater governance. Using the Mann-Whitney U test, the results showed statistical significant difference $(P=0.0001)$ between male and female responses on the effectiveness of formal institutions, norms and values. The difference is that females were more satisfied with the effectiveness of water governance institutions through water governance structures in controlling individuals' behaviour related to groundwater governance than males.

Using the Kruskal-Wallis $\mathrm{H}$ test, the differences on effectiveness of formal institutions, norms and values showed statistical significant difference between low, medium and high $(P=0.0001)$ (Table 10). The influence of water governance institutions to mediate individual behaviours in governing groundwater is manipulated by various factors including the extent of local communities' awareness on those water governance institutions (Sokile et al. 2005).

\section{Conclusions and recommendations}

The main objective of this paper was to determine effectiveness of groundwater governance structures and institutions in governing groundwater in the study area. Based on the results and discussion, the paper concludes an overall
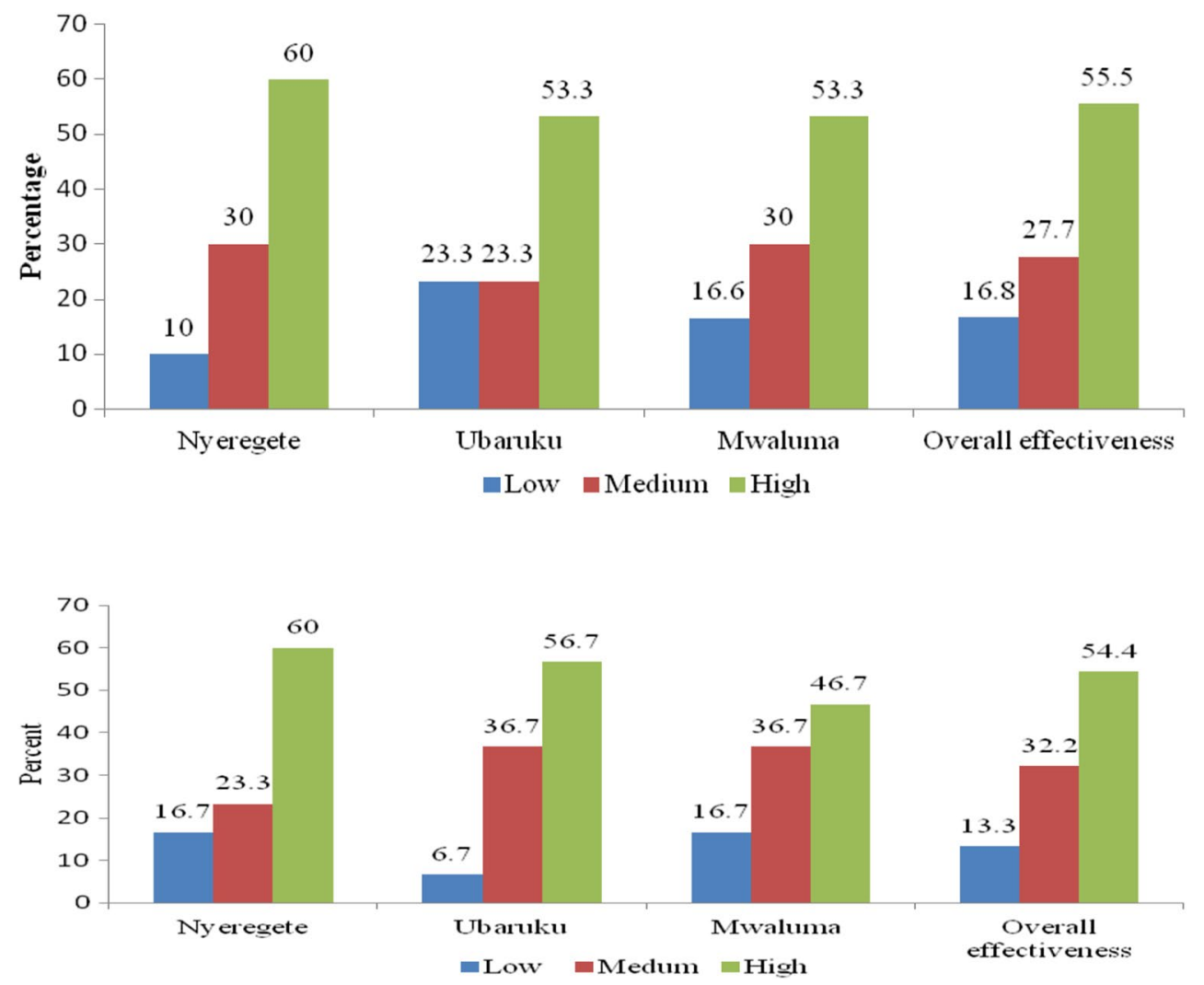
Table 10 Responses on the effectiveness on water institutions by sex $(n=90)$

\begin{tabular}{|c|c|c|c|c|c|c|c|}
\hline Sex of the respondents & $n$ & Median & & $U$ & Wilcoxon W & $Z$ & $P$ value \\
\hline \multicolumn{8}{|l|}{ Formal institutions } \\
\hline Male & 15 & 12 & & 93.500 & 213.500 & -.869 & .000 \\
\hline Female & 15 & 18 & & & & & \\
\hline \multicolumn{8}{|l|}{ Norms } \\
\hline Male & 45 & 16 & & 970.500 & 1960.500 & -.345 & .000 \\
\hline Female & 45 & 17 & & & & & \\
\hline \multicolumn{8}{|l|}{ Values } \\
\hline Male & 45 & 19 & & 928.000 & 2009.000 & -.703 & .000 \\
\hline \multirow[t]{2}{*}{ Female } & 45 & 21 & & & & & \\
\hline & $n$ & & Median & & Chi-square & $d f$ & $P$ value \\
\hline \multicolumn{8}{|c|}{ Responses on the effectiveness of water institutions $(n=90)$} \\
\hline \multicolumn{8}{|l|}{ Formal institutions } \\
\hline Low & 7 & & 9 & & & & \\
\hline Medium & 9 & & 11 & & 37.710 & 2 & 0.000 \\
\hline High & 14 & & 12 & & & & \\
\hline Total & 30 & & & & & & \\
\hline \multicolumn{8}{|l|}{ Norms } \\
\hline Low & 9 & & 11 & & & & \\
\hline Medium & 22 & & 14 & & 66.208 & 2 & 0.000 \\
\hline High & 59 & & 18 & & & & \\
\hline Total & 90 & & & & & & \\
\hline \multicolumn{8}{|l|}{ Values } \\
\hline Low & 8 & & 11 & & & & \\
\hline Medium & 24 & & 18 & & 60.660 & 2 & 0.000 \\
\hline High & 58 & & 21 & & & & \\
\hline Total & 90 & & & & & & \\
\hline
\end{tabular}

high effectiveness of the COWSO than other governance structures. Secondly, informal institutions were effective in influencing water users' behaviour on groundwater governance than formal institutions. Based on the conclusions, the paper recommends establishment of COWSOs in other villages where there were no COWSOs. In addition, the paper recommends that policy makers' should provide capacity building to governance structures at a local level on how to strength the relationship among and between different groundwater governance structures in fulfilling their responsibilities. Furthermore, the Rufiji Water Basin Office should be closer watching progress and challenges that groundwater governance structures face at a local level.

Acknowledgement This study was financed by GroFutures project, whereas its overall aim was to develop scientific basis and participatory management processes by which groundwater resources can be used sustainably for poverty alleviation in Sub-Saharan Africa for which the authors are thankful.

\section{Compliance with ethical standards}

Conflict of interest The authors have declared that they have no any conflict of interests.

Open Access This article is distributed under the terms of the Creative Commons Attribution 4.0 International License (http://creativeco mmons.org/licenses/by/4.0/), which permits unrestricted use, distribution, and reproduction in any medium, provided you give appropriate credit to the original author(s) and the source, provide a link to the Creative Commons license, and indicate if changes were made.

\section{References}

Babbie E (2007) Practice of social research. Oxford University Press, Cape Town

Calder I (2005) Blue revolution: integrated land and water resources management, 2nd edn. Earth scan, UK

Casley DJ, Kumar K (1988) Collection analysis and use of monitoring and evaluation of data. The International Bank for Reconstruction and Development, Washington, p 174 
Durant R, O'Leary R, Fiorino D (2004) Introduction in environmental governance reconsidered. Mass Press, Cambridge

Garduño H, Romani S, Sengupta B, Tuinhof A, Davis R (2011) India groundwater governance case study. [Garduño (2011) used.pdf] site visited on 23/10/2017

George D, Mallery P (2003) SPSS for windows step by step: a simple guide and reference. 11.0 update, 4th edn. Allyn and Bacon, Boston

Gudaga JL, Kabote SJ, Tarimo KPR, Mosha DB, Kashaigili JJ (2018) Groundwater users' awareness of water institutions in Tanzania: a case study of Mbarali District, Mbeya Region. J Afr Stud Dev 10(3):29-42

Hoekstra AY (2006) The global dimension of water governance: nine reasons for global arrangements in order to cope with local water problems. https:www//research.utwente.nl/en/publications/theglobal-dimension-of-water-governance-nine-reasons-for-globalarrangements.pdf

Kabote SJ, John P (2017) Water governance in Tanzania: performance of governance structures and institutions. World J Soc Sci Human $3(1): 15-25$

Kangalawe R, Mwakalila S, Masolwa P (2012) Climate change impacts, local knowledge and coping strategies in the great Ruaha river catchment area, Tanzania. Nat Resour J 2:212-223

Kashaigili JJ (2013) Chapter 13, Tanzania: In: Groundwater availability and use in Sub-Saharan Africa: a review of 15 countries. In: Pavelic P, Giordano M, Keraita B, Rao T, Ramesh V (eds) International water management institute (IWMI), Colombo, Sri Lanka, pp 195-215. https://doi.org/10.5337/2012.213

Kayombo WC (2016) Assessing meteorological data for reference evapotranspiration in Kyela and Mbarali district. J Environ Earth Sci 6(4):1-7

Kongola LRE, Nsanya G, Sadiki H (1999) Groundwater resources: development and management, an input to the Water Resources Management Policy Review (Draft), Dar es Salaam

Litvack J, Seddon J (1999) Decentralization Briefing Notes. https:// siteresources-worldbank.org/WBI/Resources/wbi37142.pd]site

Lwoga ET, Stilwell C, Ngulube P (2011) Access and use of agricultural information and knowledge in Tanzania. Libr Rev 60(5):383-395

Merrey DJ, Cook S (2012) Fostering institutional creativity at multiple levels: towards facilitated institutional bricolage. Water Altern J 5(1):1-19

Mirumachi N, Wyk E (2010) Cooperation at different scales: challenges for local and international water resource governance in South Africa. Geogr J 176:25-38

Mosha DB, Kajembe GC, Tarimo AKPR, Vedeld P, Mbeyale GE (2016) Performance of water management institutions in farmer-management irrigation schemes in Iringa rural and Kilombero-districts, Tanzania. Int J Asian Soc Sci 6(8):430-445

Ngailo JA, Mwakasendo JA, Kisandu DB (2016) Rice farming in the Southern highlands of Tanzania: management practices, socioeconomic roles and production constraints. Eur J Res Soc Sci 4(3):1-13

Pallant J (2007) Statistical package for social science (SPSS) survival manual: a step by step guide to data analysis using SPSS for windows, 3rd edn. Open University Press, Berkshire

Pavelic P, Giordano M, Keraita B, Ramesh V, Rao T (2012) Groundwater-availability and use in Sub-Saharan Africa: a review of countries. http://www.iwmi.cgiar.org/Publications/Books/PDF/ groundwater_availability_and_use_in_subsaharan_africa_a_revie w_of_15_countries.pdf

Sirima A (2016) Social and economic impacts of Ruaha national park expansion. Open J Soc Sci 4:1-11

Sokile CS, Mwaruvanda W, Koppen B (2005) Integrated water resource management in Tanzania: interface between formal and informal institutions. [http://www.sciepub.com/reference/188029

Stefano L, Svendsen M, Giordano M, Steel B, Brown B, Wolf AT (2014) Water governance benchmarking: concepts and approach framework as applied to Middle East and North Africa countries. Water Policy 16:1121-1139

URT (2000) Education in a global era: challenges to equity, Opportunity for Diversity. www.gov.go.tz/egov_uploads/documents/ EDUCATION_IN_GLOBAL_ERA_sw.pdf

URT (2002) National Water Policy. United Republic of Tanzania. http://www.NationalWater_policy.pdf

URT (2009) Water Resource Management Act no 11. Dar es Salaam, Tanzania

URT (2012) National Baseline Survey Report for Micro, Small, and Medium Enterprises in Tanzania. MSME-National-BaselineSurvey-Report.pdf

URT (2014) Mbarali District Council Strategic Plan 2013/14-2017-18; Prime Minister's Office Regional Administration and Local Government. http://www.mbaralidc.go.tz/storage/app/uploads/publi c/58d/10/58d101fccce7f653574057.pdf

Publisher's Note Springer Nature remains neutral with regard to jurisdictional claims in published maps and institutional affiliations. 